\title{
STATUS HUKUM HAK ATAS TANAH YANG TERKENA BENCANA ALAM
}

\author{
Reza Nur Amrin ${ }^{1}$, Anan Haji Imantaka ${ }^{2}$, \\ Enny Tatagelo Narince Yanengga ${ }^{3}$, Gita Cahyani Maulida ${ }^{4}$ \\ 1,2,3,4 Mahasiswa Sekolah Tinggi Pertanahan Nasional Yogyakarta, \\ Jln. Tata Bumi No. 5 Banyuraden, Kec. Gamping, Kab. Sleman, Yogyakarta \\ Koresponden email: rezanuramrin@gmail.com
}

Naskah diterima: 17 Januari 2022; revisi: 13 Februari 2022; disetujui: 15 Februari 2022

\begin{abstract}
National Agency for Disaster Management noted that during 2020 there were 4,650 disasters in Indonesia. The other effect of the loss of lives is the loss of property owned, including land. The physical condition of land parcels can change, shift, and even be destroyed, which can invalidate legal certainty from ownership of land rights. This paper discusses the legal status of land rights affected by natural disasters. The research method used was a normative method with a legal science approach in solving land problems related to the status of land rights created due to disasters. The legal status of land rights affected by the earthquake is not abolished. This is because the land object still exists, it is necessary to reconstruct the boundaries to restore the field boundaries. In the case of an abrasion disaster, the legal status of the land is destroyed because the land is also destroyed. The power of a mortgage certificate whose object is destroyed due to a natural disaster is null and void by law. This is because the Deed of Allowing Mortgage as the basis for the issuance of a mortgage certificate is null and void. After all, it does not meet the legal requirements of an agreement, namely a certain matter.
\end{abstract}

Keywords: Disaster, Legal Status, Land Rights, Abolition of Rights

\begin{abstract}
Abstrak: Badan Nasional Penanggulangan Bencana (BNPB) mencatat selama tahun 2020 telah terjadi bencana sebanyak 4.650 bencana di Indonesia. Dampak yang ditimbulkan selain memakan korban jiwa adalah kerugian atas harta benda yang dimiliki, termasuk tanah. Kondisi fisik bidang tanah dapat berubah, bergeser, bahkan musnah yang dapat menjadikan kepastian hukum dari kepemilikan hak atas tanah menjadi hapus. Tulisan ini membahas status hukum hak atas tanah yang terkena bencana alam. Metode penelitian yang digunakan metode normatif dengan pendekatan ilmu hukum dalam menyelesaikan masalah pertanahan terkait status hak atas tanah yang terdampak karena bencana. Status hukum hak atas tanah yang terkena bencana gempa bumi adalah tidak hapus. Hal ini karena objek tanah masih ada, tetapi perlu dilakukan rekonstruksi batas untuk mengembalikan batas bidang tanah. Pada kasus bencana abrasi, status hukum atas tanah adalah musnah karena tanah tersebut musnah pula. Kekuatan sertipikat hak tanggungan yang obyeknya musnah karena bencana alam adalah batal demi hukum. Hal tersebut disebabkan Akta Pemberian Hak Tanggungan (APHT) sebagai dasar dari penerbitan sertipikat hak tanggungan batal demi hukum karena tidak memenuhi syarat sah suatu perjanjian yaitu suatu hal tertentu.
\end{abstract}

Kata Kunci: bencana, status hukum, hak atas tanah, hapusnya hak

\section{A. Pendahuluan}

Undang-Undang Penanggulangan Bencana menyebutkan bahwa bencana adalah peristiwa atau rangkaiannya yang bersifat mengancam serta mengganggu kehidupan dan penghidupan masyarakat yang disebabkan oleh faktor alam dan/atau non alam maupun 
manusia sehingga menimbulkan korban jiwa manusia, kerusakan lingkungan, kerugian harta benda, dan dampak psikologis. Bencana alam adalah bencana yang diakibatkan oleh peristiwa atau serangkaian peristiwa yang disebabkan oleh alam antara lain berupa gempa bumi, tsunami, gunung meletus, banjir, kekeringan, angin topan, dan tanah longsor. Sedangkan, bencana non alam diakibatkan oleh peristiwa non alam berupa gagal teknologi, gagal modernisasi, epidemi, dan wabah penyakit. Selain bencana karena faktor alam dan/atau non alam, terdapat bencana sosial yang diakibatkan oleh manusia yang meliputi konflik sosial antarkelompok atau antar komunitas masyarakat, dan teror. Bencana alam menjadi penyumbang korban jiwa terbesar. Tercatat berbagai bencana alam dimulai dari banjir, puting beliung, tanah longsor, kebakaran hutan dan lahan, gelombang pasang dan abrasi, kekeringan, gempa bumi, dan erupsi gunung api hadir di tahun 2020 sebanyak 4.650 bencana sebagai rangkaian peristiwa yang disebabkan oleh alam. Dampak dari kerusakan bencana alam tersebut di antaranya tercatat 42.762 rumah dan 1.542 fasilitas umum rusak, mulai dari yang ringan hingga yang berat (BNPB, 2021). Kerusakan tidak hanya terjadi dari sisi bangunan dan fasilitas umum sebagai tempat berlindung makhluk hidup, tetapi juga berdampak kepada perubahan permukaan tanah.

Gempa bumi dan likuifaksi di Palu, Sulawesi Tengah pada tahun 2018 menyebabkan mayoritas bidang tanah tidak dapat di indentifikasi batas-batas bidang tanahnya secara kadastral. Banyaknya gempa tersebut disebabkan Indonesia berada di daerah Cincin Api Pasifik (ring of fire) sehingga tidak akan lepas dari ancaman gempa bumi. Direktorat Vulkanologi dan Mitigasi Bencana Geologi (DVMBG) Departemen Energi dan Sumber Daya Mineral (ESDM) menyatakan wilayah di Indonesia yang rawan gempa dan tsunami, di antarannya: Aceh, Sumatera Utara, Sumatera Barat, Bengkulu, Lampung, Banten, Jawa Tengah, Yogyakarta, Jawa Timur, Bali, Nusa Tenggara Barat, Nusa Tenggara Timur, Sulawesi Utara, Sulawesi Tenggara, Sulawesi Selatan, Maluku Utara, Maluku Selatan, Biak, Yapen dan Fak-Fak di Papua serta Balikpapan (Kementerian Pekerjaan Umum, 2010). Bencana alam tersebut mengakibatkan perbedaan posisi secara lateral dengan nilai ratarata 7,016 m di Kelurahan Balaroa, nilai rata-rata 4,273 m di Kelurahan Petobo, dan di Kelurahan Talise Valangguni senilai 3,854 m (Ratode et al., 2021). Bencana gempa dan tsunami di Indonesia di Aceh pada tanggal 26 Desember 2004 memberikan dampak bencana, sebagai berikut: 1) menghancurkan dan menghilangkan batas-batas persil tanah ataupun obyek-obyek lain yang dapat digunakan sebagai acuan keberadaan persil-persil; 2) tenggelamnya sejumlah persil tanah terutama di area pinggir pantai akibat dari melimpahnya air laut ke daratan dan penurunan tanah; 3) deformasi permukaan bumi secara horizontal dan vertikal di wilayah; 4) hilangnya surat-surat bukti hak atas tanah 
yang disimpan oleh masyarakat di rumah, arsip di kantor pertanahan, dan sertipikat yang diagunkan di bank sebagai anggunan; dan 5) meninggalnya para pemilik hak atas tanah maupun ahli warisnya (Abidin et al., 2005; Taqwaddin et al., 2012).

Kondisi Indonesia yang merupakan negara kepulauan menyebabkan memiliki banyaknya garis pantai. Indonesia memiliki garis pantai sepanjang kurang lebih $95.181 \mathrm{~km}$ serta merupakan garis pantai terpanjang kedua di dunia yang mengelilingi pulau sebanyak 17.504 pulau (Kementerian Kelautan dan Perikanan Republik Indonesia, 2019). Bencana yang dapat terjadi karena kondisi tersebut salah satunya adalah abrasi. Abrasi merupakan bentuk bencana alam lain yang dapat menimbulkan permasalahan serius terkait pertanahan. Akibat dari adanya pengikisan tanah oleh air tersebut terutama yang terjadi di pinggiran pantai dapat mengakibatkan pemilik hak atas tanah kehilangan hak untuk menguasai, menggunakan, atau mengambil manfaat atas tanah dikarenakan tanah tersebut hilang sebagian atau seluruhnya. Salah satu akibat dari adanya abrasi selama 15 tahun di Desa Pantai Bahagia, Kecamatan Muara Gembong, Kabupaten Bekasi adalah puluhan rumah ditinggalkan oleh penghuninya sendiri karena terkikis oleh air (Susilo, 2019). Kasus lain terjadi di pesisir utara Jawa, sebut saja abrasi yang terjadi di Kabupaten Demak, khususnya Kecamatan Sayung selama 20 tahun terakhir diperkirakan telah terkena abrasi mencapai 2.116,54 ha yang menyebabkan garis pantai mundur sepanjang 5,1 km dari garis pantai sejak tahun 1994 (Ondara, 2020). Hal tersebut membuat abrasi tersebut membuat abrasi ini menjadi yang terbesar tidak hanya di kawasan pantai utara dan selatan Jawa saja, melainkan terbesar di Indonesia. Daerah pesisir tersebut juga terkena banjir rob pada ketinggian 0,25 m, terutama di Desa Sriwulan, Desa Surodadi, Desa Bedono, dan Desa Timbulsloko. Hal tersebut memberi dampak berupa rusaknya salinitas air tanah, kerusakan bangunan tempat tinggal dan lahan tambak, kerusakan kendaraan atau peralatan kerja, hingga kehilangan lahan. Bagian pesisir utara Jawa lainnya juga terjadi di Kabupaten Brebes. Berdasarkan data dari Badan Penanggulangan Bencana Daerah (BPBD) Kabupaten Brebes, pada awal tahun 2020 abrasi telah terjadi abrasi mencapai kurang lebih 2.115 ha dengan rincian, sebagai berikut: 506,81 ha di Kecamatan Brebes; 626,15 ha di Kecamatan Wanasari; 1,98 ha di Kecamatan Bulakamba, 46,12 ha di Kecamatan Tanjung, dan 934,33 ha di Kecamatan Losari (Adam et al., 2020).

Perubahan batas bidang-bidang tanah bahkan musnahnya tanah tersebut menjadi dampak yang serius dari adanya bencana-bencana tersebut. Padahal tanah tersebut digunakan sebagai tempat tinggal dan tempat untuk melakukan kegiatan pemenuhan hidup. Kondisi tersebut dapat terjadi karena adanya bencana seperti gempa bumi dan abrasi. Selain kondisi fisik tanah, terkadang bukti kepemilikan hak atas tanah bisa dapat 
rusak bahkan hilang karena bencana apabila tidak diselamatkan. Apabila terdapat tanah yang mengalami kemusnahan, sesuai dengan Pasal 27, Pasal 34, dan Pasal 40 UndangUndang Pokok Agraria (UUPA) hak atas tanah tersebut menjadi hapus. Terjadinya bencana hingga mengalami kemusnahan tanah merupakan sebuah kejadian yang terjadi di luar kemampuan manusia dan tidak dapat dihindarkan. Oleh karena itu, perlunya jaminan kepastian dan perlindungan status hukum hak atas tanah bagi pemilik tanah yang terdampak suatu peristiwa bencana karena kerugian yang ditimbulkan akibat adanya bencana tidaklah sedikit.

Berdasarkan dari keresahan masyarakat mengenai status kepemilikan hak atas tanah yang dimiliki, permasalahan yang diangkat dalam penulisan ini adalah mengenai status hukum hak atas tanah yang terkena bencana. Bidang tanah yang terdampak bencana dianggap musnah atau tidak. Atas terjadinya bencana tersebut, bagaimana kepastian hukum terhadap kepemilikan hak atas tanah korban bencana di beberapa daerah terdampak? Mengingat kejelasan status, kepemilikan, dan lokasi bidang tanah tersebut sangat dibutuhkan dalam berbagai hal, seperti: menggerakkan kembali roda kehidupan, memulai proses penataan ruang, dan pembangunan infrastruktur.

\section{B. Metode Penelitian}

Metode penelitian yang digunakan dalam studi ini adalah metode yuridis normatif yaitu berdasarkan pada sumber-sumber kepustakaan seperti buku dan jurnal serta peraturan perundang-undangan dan kajian kepustakaan. Pendekatan ilmu hukum digunakan untuk menyelesaikan masalah pertanahan terkait status hak atas tanah yang terdampak karena bencana melalui. Peraturan perundang-undangan yang dikaji terlebih dahulu adalah Undang-Undang Republik Indonesia Nomor 5 Tahun 1960 tentang Peraturan Dasar Pokok-Pokok Agraria sebagai aturan awal yang menyebutkan bahwa salah satu penyebab dari hapusnya hak atas tanah adalah musnahnya tanah. Kemudian dilanjutkan aturan-aturan turunannya dan penelitian yang telah dilakukan sebelumnya untuk dilakukan analisis terkait kondisi kerusakan dari kebencanaan terkait status hak atas tanah untuk dianggap musnah atau tidaknya suatu hak atas tanah.

Lingkup bencana alam yang dipilih dalam penelitian ini adalah abrasi dan gempa bumi (termasuk tsunami dan likuifaksi) karena bencana tersebut merupakan bencana alam yang sering terjadi di Indonesia. Mengingat kondisi Indonesia yang memiliki garis pantai terpanjang kedua di dunia setelah Kanada sehingga berpotensi terjadinya abrasi serta Indonesia terletak di sepanjang jalur seismik yaitu Cincin Api Pasifik sehingga potensi gempa bumi sangat besar. 


\section{Status Hukum Hak Atas Tanah dengan Objek Tanah Terkena Gempa Bumi}

Gempa bumi adalah suatu peristiwa berguncangnya bumi karena adanya tumbukan antar lempeng bumi, aktivitas sesar, aktivitas gunung api, atau runtuhan batuan (Yanuarto et al., 2019). Bencana gempa bumi bersifat merusak, dapat terjadi setiap saat, dan berlangsung dalam waktu singkat sehingga dapat menghancurkan bangunan, jalan, jembatan, dan sebagainya dalam sekejap. Terjadinya gempa bumi dapat mengakibatkan efek sekunder berupa proses non tektonik di permukaan yang berhubungan langsung dengan gempa bumi. Likuifaksi merupakah salah satu efek sekunder dari gempa bumi yaitu sebuah fenomena pencairan tanah akibat beban gempa (beban siklik). September 2018, Indonesia kembali berduka dengan terjadinya gempa semacam ini di Sulawesi Tengah. Penyebab rentetan bencana tersebut karena terdapat pergerakan tektonik pada Patahan Palu Korro. Akibat dari bencana ini di dua kelurahan yaitu Kelurahan Balaroa sekitar 34,5 ha dan keliling 2,5 km, sedangkan di Kelurahan Petobo sekitar 158 ha dan keliling 6,58 km (Tim Pusat Studi Gempa Nasional, 2018).

Dampak gempa bumi dan likuifaksi tersebut adanya deformasi pada perubahan bentuk bidang-bidang tanah yang sudah terdaftar maupun belum terdaftar. Kondisi fisik bidang tanah pada zona gempa bumi dan likuifaksi yang dipengaruhi oleh arah aliran (pergeseran tanah) ketika gempa bumi dan likuifaksi terjadi di Palu, sebagai berikut: 1) bidang tanah tetap, yaitu bidang-bidang tanah yang posisi, bentuk, dan sisi bidang tanahnya diasumsikan tidak berubah dan tidak dipengaruhi oleh gempa bumi dan likuifaksi; 2) bidang tanah berubah sisi, yaitu pergeseran beberapa titik batas bidang tanah yang berakibat pada perubahan bentuk bidang tanah; 3) bidang tanah bergeser, yaitu bidang-bidang tanah yang mengalami perubahan atau pergeseran secara menyeluruh; dan 4) bidang tanah tidak teridentifikasi, yaitu bidang-bidang tanah yang titik batasnya sudah tidak dapat diidentifikasi kembali karena perubahan struktur dan kondisi geografi tanah. Sedangkan, kondisi pada zona gempa bumi menunjukkan adanya pergeseran bidangbidang tanah bersama dengan bangunan di atasnya yang dapat mengakibatkan munculnya ruang (bidang) baru tanpa klaim pemilik atau tanah timbul (Ratode et al., 2021).

Efek lain akibat adanya gempa bumi adalah tsunami. Hal tersebut apabila gempa bumi terjadi di dasar laut sehingga mengakibatkan gelombang air besar. Seperti halnya pada tahun 2004, bencana alam gempa bumi dan tsunami terjadi di Aceh. Salah satu permasalahan yang terjadi pasca bencana alam tersebut adalah rusak dan hilangnya sertipikat hak atas tanah disertai dengan hancurnya batas-batas tanah. Hal tersebut berdampak terhadap sulitnya korban bencana alam tsunami Aceh memperoleh jaminan kepastian dan perlindungan hukum yang efektif terhadap hak kepemilikan atas tanah. 
Status tanah yang disebabkan oleh bencana gempa bumi tidak dianggap sebagai tanah musnah. Kondisi tanah mengalami perubahan posisi serta batas-batas bidang tanah di atas permukaan tanah. Para pemegang hak atas tanah masih memiliki hak-hak atas tanahnya dan mereka bisa menggunakan hak-hak tersebut. Bentuk perlindungan status hukum hak atas tanah akibat terjadinya bencana gempa bumi dan likuifaksi di antaranya adalah inventarisasi subjek dan objek kepemilikan bidang tanah yang terkena dampak, rekonstruksi batas bidang tanah, sesuai dengan ketentuan Petunjuk Teknis PMNA 3/1997, menyelenggarakan kegiatan pengadaan tanah untuk pembangunan hunian tetap bagi korban likuifaksi, gempa bumi, dan tsunami serta perlu dilakukannya perubahan tata ruang wilayah Kota Palu dengan pola mitigasi bencana (Ellisa, 2019; Lestari, 2021; Ratode et al., 2021).

Contoh lain pada kejadian gempa bumi dan tsunami di Aceh yang merenggut banyak korban serta hilangnya batas-batas persil tanah. Mengingat kejelasan status, kepemilikan dan lokasi persil tanah sangat dibutuhkan untuk menggerakkan kembali roda kehidupan, memulai proses penataan ruang, dan pembangunan infrastruktur, maka perekonstruksian batas persil tanah di Aceh perlu dilaksanakan secara cepat, akurat, dan disepakati oleh komunitas di kawasan keberadaan persil yang bersangkutan. Kegiatan tersebut dilakukan dengan melakukan kombinasi informasi dari pemilik tanah, ahli waris ataupun pemuka masyarakat, informasi sertipikat tanah dari BPN, informasi data geometrik persil PBB dan BPHTB, dan citra satelit beresolusi tinggi (Abidin et al., 2005; Ellisa, 2019). Adanya kegiatankegiatan pasca bencana tersebut merupakan bentuk upaya perlindungan hukum yang diberikan pemerintah terhadap korban bencana alam tsunami Aceh terkait perlindungan hukum hak atas tanah pasca tsunami Aceh. Kebijakan lain yang diberikan oleh pemerintah terkait perlindungan hukum hak atas tanah, yaitu pelaksanaan pendaftaran ulang secara sistematis berbasis masyarakat melalui program RALAS (Reconstruction of Aceh Land Administration System) yang dilakukan secara serentak meliputi semua objek pendaftaran tanah yang ada di wilayah suatu desa atau kelurahan yang merupakan lokasi bencana tsunami di Aceh (Yulianti, 2013). Kegiatan identifikasi pemilikan hak atas tanah dilakukan oleh Badan Pertanahan Nasional dan Badan Rekonstruksi dan Rehabilitasi, pemberian Hak Waris dan Perwalian ditetapkan dengan musyawarah oleh keputusan Hakim Mahkamah Syariah. Pemberian Hak Waris dan Perwalian Anak di bawah umur dengan pengisian formulir Kesepakatan Pewarisan dan Kesepakatan Perwalian dengan penetapan Hakim Mahkamah Syariah (Sari, 2006).

Rekonstruksi dan rehabilitasi bencana gempa bumi dapat dikaitkan dengan kegiatan reforma agraria agar terwujudnya penguasaan, pemilikan, penggunaan, dan pemanfaatan 
tanah (P4T) dan ruang sesuai rencana tata ruang serta usaha penyediaan tanah untuk kepentingan umum sebagai perwujudan untuk meningkatkan kualitas lingkungan dan pemeliharaan sumber daya alam melalui pelibatan partisipasi aktif masyarakat yaitu Konsolidasi Tanah yang diimplementasikan dalam PMNA/Ka. BPN No. 12 Tahun 2019. Hal tersebut dapat menjadi wajib sebagai upaya dalam penataan kawasan pasca bencana, konflik, kawasan kumuh dan program strategis. Dalam hal ini, bencana yang dimaksud adalah bencana yang dapat mengakibatkan terjadinya perubahan batas bidang tanah, tanah musnah, perubahan struktur P4T sehingga perlu dilakukannya penataan kembali dan/atau relokasi.

\section{Status Hukum Hak Atas Tanah dengan Objek Tanah Terkena Abrasi}

Berdasarkan Pasal 66 Peraturan Pemerintah Nomor 18 Tahun 2021 disebutkan tanah yang sudah berubah dari bentuk asalnya karena peristiwa alam dan tidak dapat diidentifikasi lagi sehingga tidak dapat difungsikan, digunakan, dan dimanfaatkan sebagaimana mestinya, dinyatakan sebagai tanah musnah melalui penetapan tanah musnah dengan tahapan yaitu identifikasi, inventarisasi, dan pengkajian. Peristiwa alam yang dapat menyebabkan terjadinya tanah musnah adalah abrasi. Abrasi (erosi pantai) adalah proses pengikisan pantai oleh tenaga gelombang laut dan arus laut yang bersifat merusak. Hal tersebut dipicu oleh terganggunya keseimbangan alam daerah pantai tersebut yang disebabkan oleh gejala alami maupun manusia. Rentannya wilayah pesisir terhadap degradasi lingkungan seperti kerusakan habitat, pencemaran lingkungan, eksploitasi sumber daya alam yang berlebihan, konversi kawasan lindung menjadi pembangunan, bencana alam, dan abrasi pantai. Perubahan garis pantai dan pengikisan tanah menjadi salah satu dampak dari hal tersebut. Kondisi tanah pada kasus abrasi adalah musnah karena sudah ditutupi oleh air laut. Hal tersebut dapat menyebabkan penguasaan tanah tersebut kembali menjadi milik pemerintah.

Perlindungan hukum dibagi menjadi dua macam yaitu perlindungan hukum preventif digunakan untuk melakukan pencegahan terjadinya sengketa terhadap suatu permasalahan dan perlindungan hukum represif bertujuan untuk menyelesaikan adanya sengketa setelah suatu permasalahan tersebut timbul (Hadjon, 1987). Oleh karena itu, perlu dilihat kembali peran pemerintah dalam mencegah terjadinya abrasi. Sebagai contoh, pada kasus abrasi di Kabupaten Brebes, pemerintah berusaha melakukan perlindungan preventif berupa meniadakan penggalian pasir pantai, membuat media atau saraba pemecah ombak oleh beton, penanaman kembali hutan mangrove, dan pelestarian terumbu karang. Pemerintah tidak sepenuhnya dianggap bersalah karena telah melakukan 
tindakan preventif untuk mencegah terjadinya kerusakan apabila terjadi bencana. Negara tidak dapat memberikan perlindungan hukum terhadap hapusnya hak atas tanah karena tanahnya musnah. Hal tersebut karena sesuai ketentuan dalam Pasal 27 UUPA huruf b tentang hapusnya hak atas tanah, tanah yang musnah berarti tanahnya hapus. Pengaturan ini jelas bahwa tidak ada perlindungan mengenai tanah yang telah hilang akibat fenomena alam yang terjadi. Negara tidak mempunyai kewajiban untuk memberikan perlindungan kepada masyarakat yang kehilangan tanahnya karena abrasi di pinggir pantai.

Pasal 5 Undang-Undang Nomor 24 Tahun 2007 mengatakan bahwa pemerintah dan pemerintah daerah wajib menjadi penanggung jawab dalam rangka penyelenggaraan penanggulangan bencana sehingga dengan adanya tindakan preventif oleh pemerintah ia tidak bisa dianggap melanggar hukum dan tidak bertanggung jawab. Pemerintah tidak memiliki kewajiban untuk bertanggung jawab apabila sudah terjadi hilangnya tanah karena fenomena alam. Hal-hal yang diatur di dalam undang-undang hanya memberikan perlindungan sebatas upaya-upaya preventif, tetapi tidak memiliki jaminan pasti di kemudian hari jika upaya yang telah dilakukan mengalami kegagalan dalam perjalanannya. Hilangnya tanah karena faktor alam, seperti abrasi tidak dapat dimintai pertanggungjawaban terhadap negara, kecuali apabila pemerintah terbukti tidak melakukan upaya-upaya pencegahan. Apabila masyarakat merasa upaya-upaya tindakan pencegahan tersebut kurang tepat dalam mencegah abrasi maka masyarakat setempat dapat mengajukan gugatan Class Action melalui Pengadilan Negeri setempat (Adam et al., 2020).

Sebelum tanah musnah dicatat administrasinya, pemegang hak diberikan prioritas untuk melakukan rekonstruksi atau reklamasi atas pemanfaatan tanah yang dilakukan oleh pemerintah baik pusat maupun daerah atau pihak lain melalui bantuan dana kerohiman, kemudian berdasarkan sosialisasi yang dipaparkan Direktorat Jenderal Penetapan Hak dan Pendaftaran Tanah mengenai Peraturan Pemerintah Nomor 18 Tahun 2021, tahapantahapan pelaksanaan kegiatan penegasan tanah musnah perlu dilakukan, sebagai berikut: 1) Bupati/Walikota membentuk Tim Peneliti, yang terdiri dari: Asisten Bupati/Walikota yang membidangi pemerintahan dan pertanahan, Kepala Kantor Pertanahan selaku Wakil Ketua Tanah Musnah, unsur dari instansi yang membidangi Kelautan dan Perikanan, unsur dari Badan Informasi Geospasial, unsur dari Balai Sumber Daya Air (Kementerian Pekerjaan Umum dan Perumahan Rakyat), unsur dari Lembaga Akademisi, Camat, Lurah/Kepala Desa, instansi lain apabila diperlukan, dan Pejabat Kantor Pertanahan yang ditunjuk oleh Kepala Kantor Pertanahan; 2) identifikasi dan inventarisasi; 3) penelitian dan pengkajian; pengumuman dan pemanggilan; rekonstruksi dan reklamasi (dana 
kerohiman); penegasan tanah musnah; dan mengadministrasikan tanah musnah. Kemudian dilakukan pendaftaran sesuai Pasal 52 Peraturan Pemerintah Nomor 24 Tahun 1997 yang dilakukan oleh Kepala Kantor Pertanahan dengan membubuhkan catatan pada buku tanah dan surat ukur serta memusnahkan sertifikat hak yang bersangkutan, berdasarkan data dalam buku tanah, salinan surat keputusan Pejabat yang berwenang mengenai hak yang bersangkutan telah dibatalkan/dicabut, dan akta yang menyatakan bahwa hak yang bersangkutan telah dilepaskan oleh pemegang haknya serta apabila tidak diserahkan kepada Kepala Kantor Pertanahan, dilakukan pencatatan pada buku tanah dan surat ukur yang bersangkutan.

\section{E. Status Hukum Hak Tanggungan dengan Objek Tanah Musnah}

Musnahnya obyek jaminan hak tanggungan dikarenakan keadaan force majeure atau overmacht tidak diatur secara tegas dalam ketentuan Undang-Undang Hak Tanggungan. Kekuatan sertipikat hak tanggungan yang obyeknya musnah karena bencana alam adalah batal demi hukum. Hal tersebut disebabkan Akta Pemberian Hak Tanggungan (APHT) sebagai dasar dari penerbitan sertipikat hak tanggungan batal demi hukum karena tidak memenuhi syarat sah suatu perjanjian yaitu suatu hal tertentu sesuai Pasal $1320 \mathrm{KUH}$ Perdata. Benda (objek) hak tanggungan dalam APHT telah musnah terkena bencana alam sehingga kekuatan mengikat serta eksekutorial sertipikat hak tanggungan yang obyeknya musnah karena bencana alam menjadi hapus. Maka, hapusnya hak atas tanah mengakibatkan hak tanggungan menjadi hapus atau hilang pula (Tarigan, 2015; Jaya et al., 2017; Khasanah \& Alfons, 2021).

Perlindungan hukum preventif (pencegahan) bagi kreditur dan debitur dilakukan dengan mengasuransikan obyek yang dijadikan jaminan. Perlindungan hukum represif (pasca terjadi) untuk kreditur adalah dengan cara pembayaran klaim asuransi kepada kreditur atas musnahnya obyek hak tanggungan yang menjadi jaminan debitur. Perlindungan represif untuk debitur adalah dengan pembayaran sisa uang klaim setelah dikurangi dengan kredit debitur pada kreditur, apabila uang klaim tersebut tersisa uang klaim tersebut dapat diberikan kepada debitur, selain itu perlindungan represif yang dapat diberikan kepada debitur adalah dengan melakukan restrukturisasi terhadap fasilitas kredit yang dimiliki debitur (Azis, 2019; Khasanah \& Alfons, 2021).

\section{F. Kesimpulan}

Kondisi Indonesia yang merupakan negara kepulauan membuat Indonesia memiliki garis pantai terpanjang kedua di dunia dapat berpotensi terjadinya abrasi serta letaknya 
yang berada di sepanjang jalur seismik yaitu Cincin Api Pasifik dapat pula berpotensi besar terjadi gempa bumi. Banyaknya bencana sering menimbulkan banyak korban dan kerugian materil termasuk kepastian dari status hukum hak atas tanah. Kepastian hukum terhadap kepemilikan hak atas tanah korban bencana di beberapa daerah terdampak dapat dibedakan menurut dampak yang ditimbulkan, sebagai berikut:

1. Status hukum hak atas tanah yang terkena bencana gempa bumi adalah tidak hapus. Hal ini karena objek tanah masih ada, tetapi perlu dilakukan rekonstruksi batas untuk mengembalikan batas bidang tanah. Solusi lain adalah merelokasi tempat dari kawasan bencana menuju kawasan yang lebih aman dari bencana gempa bumi melalui konsolidasi tanah yang dilakukan oleh pemerintah dengan bantuan partisipatif masyarakat;

2. Status hukum hak atas tanah yang terkena abrasi adalah musnah karena tanah yang dilekati hak atas tanah tersebut musnah pula. Negara tidak dapat memberikan perlindungan hukum terhadap tanah yang musnah. Berdasarkan UUPA mengenai hapusnya hak atas tanah, salah satu penyebabnya adalah musnahnya tanah. Oleh sebab itu, hilangnya tanah karena faktor alam, seperti abrasi tidak dapat dimintai pertanggungjawaban terhadap negara, terkecuali jika pemerintah terbukti tidak melakukan upaya-upaya pencegahan yang semestinya; dan

3. Kekuatan sertipikat hak tanggungan yang obyeknya musnah karena bencana alam adalah batal demi hukum karena disebabkan Akta Pemberian Hak Tanggungan (APHT) sebagai dasar dari penerbitan sertipikat hak tanggungan batal demi hukum karena tidak memenuhi syarat sah suatu perjanjian yaitu suatu hal tertentu.

\section{Daftar Pustaka}

Abidin, H. Z., Meilano, I., Heryani, E., Budiwibowo, A., Bachri, S., Rommel, E., \& Yanto, B. A. (2005). Rekonstruksi Batas Persil Tanah di Aceh Pasca Tsunami: Beberapa Aspek dan Permasalahannya. Jurnal Infrastruktur dan Lingkungan Binaan, 1(2), 1-10.

Adam, C. K., Walpa, J. A., \& Octavia, V. (2020). Pertanggungjawaban Pemerintah Republik Indonesia Terhadap Hilangnya Hak Atas Tanah Milik Warga Masyarakat Yang Terkena Abrasi di Wilayah Kabupaten Brebes Jawa Tengah. Cepalo, 4(2), 129-142.

Azis, F. (2019). Upaya Hukum Atas Hilangnya Obyek Hak Tanggungan Karena Bencana Alam Di Mangkang Wetan Kota Semarang (Skripsi S1). Universitas Semarang. Semarang.

Badan Nasional Penanggulangan Bencana. (2021, Juli). Bencana Indonesia 2020: Sebaran Kejadian Bencana Alam Tanggal 1 Januari - 31 Desember 2020. Diakses tanggal 16 Januari 2022 dari https://gis.bnpb.go.id/. 
Ellisa, D. A. (2019). Status Hak Atas Tanah Pasca Likuifaksi di Kota Palu (Tesis S2). Universitas Airlangga, Surabaya.

Hadjon, P. M. (1987). Perlindungan Hukum Bagi Rakyat di Indonesia: Sebuah Studi Tentang Prinsip-Prinsipnya, Penanganannya oleh Pengadilan dalam Lingkungan Peradilan Umum dan Pembentukan Peradilan Administrasi Negara. Surabaya: Bina Ilmu.

Jaya, I. G. P., Utama, I. M. A., \& Westra, I. K. (2017). Kekuatan Hukum Sertifikat Hak Tanggungan Dalam Hal Musnahnya Obyek Hak Tanggungan Karena Bencana Alam. Jurnal Ilmiah Prodi Magister Kenotariatan, 2, 277-285.

Kementerian Kelautan dan Perikanan Republik Indonesia. (2019, Agustus). Laut Masa Depan Bangsa, Mari Jaga Bersama. Diakses tanggal 16 Januari 2022 dari https://kkp.go.id/artikel/12993-laut-masa-depan-bangsa-mari-jaga-bersama.

Kementerian Pekerjaan Umum. (2010, Juli). Peta Zonasi Gempa Indonesia. Diakses tanggal 13 Februari 2022 dari https://eppid.pu.go.id.

Khasanah, D. D., \& Alfons. (2021). Analisis Yuridis Akibat dari Musnahnya Obyek Jaminan yang Dilekati Hak Tanggungan Karena Bencana Alam. Widya Bhumi, 1(2), 149-159.

Lestari, N. (2021). Status Hak Atas Tanah Pasca Bencana Likuifaksi dan Rencana Tata Ruang Wilayah Di Kota Palu. Jurnal Hukum dan Kenotariatan, 5(1), 160-172.

Ondara, K. (2020, Februari). Laju Perubahan Garis Pantai Kecamatan Sayung, Demak - Jawa Tengah 2008-2018. Diakses tanggal 16 Januari 2022 dari https://lrsdkp.litbang.kkp.go.id/kabar-terbaru/47-artikel/artikel-litbang-2020/570laju-perubahan-garis-pantai-kecamatan-sayung-demak-jawa-tengah-2008-2018.

Ratode, H. K., Nugroho, T., \& Sufyandi, Y. (2021). Analisis Perubahan Bidang Tanah Terdaftar Akibat Gempabumi dan Likuifaksi Palu Tahun 2018. Jurnal Tunas Agraria, $4(1), 82-94$.

Sari, F. (2006). Tata Laksana Kepemilikan Hak Milik Atas Tanah Pasca Gempa dan Tsunami di Kecamatan Meuraxa: Suatu Penelitian di Kota Banda Aceh (Tesis S2). Universitas Sumatera Utara, Medan.

Susilo, T. (2019, Desember). Duh! Abrasi 15 Tahun Buat Kampung di Bekasi ini Ditinggalkan. $\begin{array}{lllll}\text { Diakses } & \text { tanggal } & 16 & \text { Januari }\end{array}$ https://www.cnbcindonesia.com/news/20191210100126-7-121758/duh-abrasi-15tahun-buat-kampung-di-bekasi-ini-ditinggalkan.

Taqwaddin, Tripa, S., Ansari, M. I., \& Mansur, T. M. (2012). Penyelesaian Tanah Korban Tsunami yang Tidak Ada dan/atau Tidak Diketahui Ahli Warisnya. Jurnal Media Hukum, 19(2), 251-263. 
Tarigan, D. (2015). Kewajiban Debitur untuk Mengasuransikan Barang Agunan dengan Hak Tanggungan dalam Perjanjian Kredit di Bank Pemerintah dan Swasta. Premise Law Journal, 3, 1-20.

Tim Pusat Studi Gempa Nasional. (2018). Kajian Gempa Palu Provinsi Sulawesi Tengah 28 September 2018 (M7.4). Bandung: Pusat Penelitian dan Pengembangan Perumahan dan Permukiman, Badan Penelitian dan Pengembangan, Kementerian Pekerjaan Umum dan Perumahan Rakyat.

Yanuarto, T., Pinuji S., Utomo A. C., \& Satrio, I. T. (2019). Buku Saku: Tanggap Tangkas Tangguh Bencana. Jakarta: Pusat Data Informasi dan Humas BNPB.

Yulianti, D. E. (2013). Perlindungan Hukum Terhadap Musnahnya Hak Kepemilikan Atas Tanah Akibat Bencana Alam Tsunami di Aceh Berdasarkan Undang-Undang Nomor 5 Tahun 1960 Tentang Peraturan Dasar Pokok-Pokok Agraria (Skripsi S1). Universitas Padjajaran, Bandung.

\section{Peraturan Perundang-Undangan}

Kitab Undang-Undang Hukum Perdata (KUH Perdata)

Undang-Undang Republik Indonesia Nomor 5 Tahun 1960 tentang Peraturan Dasar PokokPokok Agraria

Undang-Undang Republik Indonesia Nomor 4 Tahun 1996 tentang Hak Tanggungan atas Tanah Beserta Benda-Benda yang Berkaitan dengan Tanah

Undang-Undang Republik Indonesia Nomor 24 Tahun 2007 tentang Penanggulangan Bencana

Peraturan Pemerintah Republik Indonesia Nomor 24 Tahun 1997 tentang Pendaftaran Tanah

Peraturan Pemerintah Republik Indonesia Nomor 18 Tahun 2021 tentang Hak Pengelolaan, Hak Atas Tanah, Satuan Rumah Susun, dan Pendaftaran Tanah

Peraturan Menteri Negara Agraria/Kepala Badan Pertanahan Nasional Nomor 3 Tahun 1997 tentang Ketentuan Pelaksanaan Peraturan Pemerintah Nomor 24 Tahun 1997 Tentang Pendaftaran Tanah

Peraturan Menteri Agraria dan Tata Ruang/Kepala Badan Pertanahan Nasional Republik Indonesia Nomor 12 Tahun 2019 tentang Konsolidasi Tanah 